\title{
Digital Literacy of Doctoral Program Student in Sports Education, Semarang State University
}

\author{
Sri Wicahyani ${ }^{1}$, Soegiyanto KS ${ }^{2}$, Dwi Cahyo Kartiko ${ }^{3}$, Septian Williyanto ${ }^{4}$ \\ \{ sriwicahyani@unesa.ac.id ${ }^{1}$, soegiyanto.ks@mail.unnes.ac.id², dwicahyokartiko@unesa.ac.id ${ }^{3}$, \\ septianwilliyanto@upi.edu $\left.{ }^{4}\right\}$
}

Universitas Negeri Surabaya, Surabaya, Indonesia ${ }^{1,3}$

Universitas Negeri Semarang, Semarang, Indonesia ${ }^{2}$

Universitas Pendidikan Indonesia, Jakarta, Indonesia ${ }^{4}$

\begin{abstract}
E-learning in new normal era is a product of transformation from conventional to digital-based learning. Students' digital literacy will affect the success of achievement in learning system. The purpose of this research is to identify students' digital literacy in order to support the implementation of e-learning in Sports Education Doctoral Program at Semarang State University. The method used is descriptive with a quantitative approach. 56 pupils as subjects of the study, likewise sampling quota applied as the sampling technique. The data analysis used is descriptive analysis. The results shows that students mastery on various e-learning system platforms was in the "Medium" category, mastery of various social media as part of the "High" category of e-learning, mastery of video conference applications in the "Medium" category, and mastery of the supporting media for making assignment is "High" category either.
\end{abstract}

Keywords: digital literacy, e-learning, new normal era

\section{Introduction}

The new normal is a scenario to accelerate the handling of the COVID-19 pandemic in the health and socio-economic aspects of the community. The term new normal focuses more on cultural changes in the community to be accustomed to having a healthy lifestyle according to health protocols. Habits such as frequent hand washing with soap and running water, wearing masks when traveling, avoiding crowds, and also maintaining physical distance when interacting with other people (physical distancing).

The application of social distancing and physical distancing requires that the teaching and learning process cannot face each other or meet in the classroom. The effectiveness of this social distancing policy will be realized if the lecture process is carried out with a long-distance lecture system and uses an online platform [1]. This policy is implemented globally so that all educational activities are transformed using digital media with an online system. Online lectures with the full application of e-learning are options that must be taken in the midst of the current situation.

The readiness of various students is the focus of attention both from student resources and access to computers and where they are or where the students are located. The quality of learning success using the e-learning method has been carried out by several studies. Among these successes are the communication factor between lecturers and students, as well as feedback from lecturers [2]. The readiness of students in online learning can be assessed from aspects, 
namely equipment capability, technology skills, independent learning, motivation, and perceived usefulness. The capability of the device is related to online learning readiness in terms of facilities, particularly computer equipment and internet access. Technology skills are related to the ability of students to access and use technology, particularly information and communication technology [3].

The e-learning system is a form of learning implementation using the internet in the form of various multimedia content and application platforms and social media. E-learning is a transformation from conventional learning to digital-based. Student resources in implementing e-learning greatly influence the success of achievement. Mastery and the use of technology to interact and communicate is a must to support the e-learning process.

The latest technology offers various kinds of digital media that can be used in communicating and socializing. Digital media now facilitates communication and virtual interactions as an alternative to face-to-face learning. Interaction in digital media requires not only technical skills to access technology but also content understanding, active and interactive functions in generating messages. Many digital media, both socialization media, interaction, communication and mass conferences can be accessed and downloaded for free and easy to use.

Digital literacy is a person's ability to use various digital media. Literally, digital literacy can be defined by deriving the definition of the words 'literacy' and 'digital'. Literacy is defined as the ability to read and write, while digital can be interpreted as a format for writing and reading on a computer. When assembled, digital literacy can be interpreted as the ability to operate a computer to read and write in a digital format [4]. Digital literacy is a basic need for people to live effectively and efficiently in the 21 st century era [5]. The development of the digital world is used to improve the ability to find, use, summarize, evaluate, create and communicate information. In its development, digital literacy is the interest, attitude and ability of individuals to use digital technology and communication tools to access, manage, integrate, analyze and evaluate information, build new knowledge, create and communicate with others in order to participate effectively in society. Digital literacy activities have been synonymous with a person's ability to use and understand the use of information and communication technology, for example, in supporting the world of education and the economy [6].

High digital literacy skills can make it easier for students to follow every lecture process from preparation to evaluation. For example, the ability to connect hardware devices to the internet network and install various software for online lectures. Digital literacy is very supportive of student skills in the lecture process and in completing college assignments. In the lecture process, students must be able to use various platforms and applications according to those used by each lecturer. In addition, in completing assignments, students must also be skilled in utilizing all-digital tools to independently find learning resources and other information apart from those provided by the lecturer.

Mastery of the e-learning system platform is one of the supporting factors for the success of the online learning process and achievement. The platforms that are currently widely used in the delivery of material and lectures include Google Form, Google Class, Moodle, Edmodo and so on. The platform used is one that provides practical features, is easy, does not cost money to use. The completeness of the application menu is also a consideration for choosing an online learning platform. Many institutions that already have an online lecture portal which is specially designed for the benefit of the campus. Like Semarang State University, it has an online learning portal, namely Elena. Distribution of materials, submission of assignments and evaluation can be done on the portal.

Social media, which is generally the main alternative in communication in delivering lecture schedules, includes Whatsapp, Twitter, Instagram, Facebook, Telegram and so on. This 
social media is a communication bridge and indirect interaction between students and lecturers and education staff. Communication can be done personally between individuals and in groups in groups.

The video converence application used in the material delivery process is very important to master as a substitute for face-to-face learning. Lectures will virtually present interaction and communication between one student and another student and student and lecturer. Here the role of students as individuals and groups can be created in various learning models so that feedback, discussion and questions and answers emerge in the forum. This is done so that students do not get bored of following lectures in front of a laptop. Some of the video converence platforms that are often used are Zoom meeting, Jitsi, Google Meet, Teams, Cisco Webex and others. Ease and practicality as well as complete features are considered in choosing the converence video platform.

Supporting media for online assignments is no less important in order to support the achievement of learning outcomes. Student skills in finding information and assignment references, then processing and presenting assignments and collecting are a series that require mastery of digital media. Some of the supporting media for online assignments are email, scanner, file converter, file compressor, video/picture editor and so on. The editing process is carried out as part of the lecturers' efforts to make students think creatively and innovatively.

\section{Methods}

This research is a quantitative descriptive study, namely analyzing, describing, and summarizing various conditions, situations from various data collected using a Likert scale. The population in this study were students of the Semarang State University Sports Education Doctoral Program class of 2017-2020. The sampling technique was quota sampling, namely 56 students with an error tolerance of $10 \%$ based on determining the minimum sample size in the Isaac \& Michael table. The instrument used in this study was a packaged questionnaire using a Google form with several question indicators. Researchers ask closed questions with a response that has been determined by the researcher to avoid widespread data results. After the data collection is complete, it is followed by data reduction. The data are analyzed statistically to show trends in the responses given by the target sample to the phenomena being discussed. The instrument has been consulted with digital media expert validators and has been tested on a small scale to obtain the validity and reliability of the instrument. In this study, the data analysis technique in this study is descriptive analysis. Descriptive data analysis technique is an analysis technique used to analyze data by describing or describing the data that has been collected improperly without any intention of making generalizations from the research results. Included in descriptive statistical data analysis techniques such as presenting data in the form of graphs, tables, percentages, frequencies, diagrams or graphs. The data processing technique was carried out through several stages, namely editing, coding and tabulation using SPSS 22. This study used a frequency table and a score table at the digital literacy level. There are three levels of categories in this study, namely "High", "Medium" and "Low". The determination of this category is based on the assumption that the subject population scores are normally distributed. The category levels are as follows: 
Table 1. Score category

\begin{tabular}{ll}
\hline Category & Score \\
\hline High & $\geq 205,3$ \\
Medium & $130,7-205,2$ \\
Low & $\leq 130,6$ \\
\hline
\end{tabular}

Source: Researcher

\section{Result}

\subsection{Mastery of the e-learning system platform}

Mastery of the e-learning platform is one of the supporting factors for the success of the online learning process and achievement. The e-learning platform presents a variety of features that can be used as a medium for sharing material, assignments, accommodating assignments by students and assessing student assignments by lecturers. The following is student digital literacy data on mastery of the e-learning system platform:

Table 2. Mastery of digital literacy in e-learning system platform

\begin{tabular}{lcc}
\hline \multicolumn{1}{c}{ Platform } & Score & Category \\
\hline Google form & 192 & Medium \\
Google classroom & 193 & Medium \\
Elena & 159 & Medium \\
Moodle & 110 & Low \\
Etmodo & 124 & Low \\
\hline \multicolumn{1}{c}{ Average } & 156 & Medium \\
\hline
\end{tabular}

Source: Research Data

The table above shows that the average student mastery of the e-learning platform is in the 'Medium' category.

Table 3. Percentage of digital literacy mastery for the E-Learning system platform

\begin{tabular}{lccccc}
\hline \multicolumn{1}{c}{ Aspect } & Google form & Google classrom & Elena & Moodle & Edmodo \\
\hline $\begin{array}{l}\text { Mastering editing, collecting } \\
\text { data, creating and filling content }\end{array}$ & $21,43 \%$ & $19,64 \%$ & $17,86 \%$ & $3,57 \%$ & $5,36 \%$ \\
$\begin{array}{l}\text { Mastering content creation and } \\
\text { filling }\end{array}$ & $19,64 \%$ & $23,21 \%$ & $23,21 \%$ & $3,57 \%$ & $1,79 \%$ \\
Mastering content filling & $39,29 \%$ & $41,07 \%$ & $5,36 \%$ & $19,64 \%$ & $23,21 \%$ \\
Just knowing & $19,64 \%$ & $14,29 \%$ & $32,14 \%$ & $32,14 \%$ & $48,21 \%$ \\
Do not know & $0,00 \%$ & $1,79 \%$ & $21,43 \%$ & $41,07 \%$ & $21,43 \%$ \\
\hline \multicolumn{1}{c}{ Amount } & $100 \%$ & $100 \%$ & $100 \%$ & $100 \%$ & $100 \%$ \\
\hline
\end{tabular}

Source: Research Data 
The table above shows that on the Google Form platform the majority of students have mastered editing, collecting data, creating and filling in content. On the Google Classroom platform, the majority of students master content filling. On the Elena platform, the majority of students only know about Elena. On the Moodle platform, the majority of students do not know about Moodle. On the Edmodo platform, the majority of students only know about Edmodo.

\subsection{Mastery of social media}

Mastery of social media as part of e-learning cannot be separated from supporting the successful preparation, process and learning achievement. This social media is a bridge for students and lecturers in communication and interaction in preparation for conducting lecture activities such as sharing lecture schedule information, virtual converence links, and other important information that lecturers and students want to convey. The following is student digital literacy data on social media mastery:

Table 4. Mastery of digital literacy in social media

\begin{tabular}{lcc}
\hline \multicolumn{1}{c}{ Platform } & Score & Category \\
\hline Whatsapp & 258 & High \\
Twitter & 204 & High \\
Instagram & 242 & High \\
Facebook & 236 & High \\
Telegram & 228 & High \\
\hline \multicolumn{1}{c}{ Average } & 234 & High \\
\hline
\end{tabular}

Source: Research Data

The table above shows that the students' average social media mastery is in the "High" category.

Table 5. Percentage of digital literacy for social media mastery

\begin{tabular}{lccccc}
\hline \multicolumn{1}{c}{ Aspect } & Whatsapp & Twitter & Instagram & Facebook & Telegram \\
\hline $\begin{array}{l}\text { Mastering how to send files, } \\
\text { images, videos and editing }\end{array}$ & $76,79 \%$ & $39,29 \%$ & $58,93 \%$ & $55,36 \%$ & $48,21 \%$ \\
$\begin{array}{l}\text { Mastering the use \& creation } \\
\text { of personal \& group accounts }\end{array}$ & $7,14 \%$ & $17,86 \%$ & $25,00 \%$ & $23,21 \%$ & $23,21 \%$ \\
$\begin{array}{l}\text { Mastering receiving \& sending } \\
\text { messages or calls }\end{array}$ & $16,07 \%$ & $12,50 \%$ & $5,36 \%$ & $8,93 \%$ & $16,07 \%$ \\
Just knowing & $0,00 \%$ & $28,57 \%$ & $10,71 \%$ & $12,50 \%$ & $12,50 \%$ \\
Do not know & $0,00 \%$ & $1,79 \%$ & $0,00 \%$ & $0,00 \%$ & $0,00 \%$ \\
\hline \multicolumn{1}{c}{ Amount } & $100 \%$ & $100 \%$ & $100 \%$ & $100 \%$ & $100 \%$ \\
\hline
\end{tabular}

Source: Research Data

The table above shows that in the Whatsapp, Twitter, Instagram, Facebook and Telegram applications the majority of students have mastered how to send files, images, videos and editing. 


\subsection{Mastery of video conferencing applications}

Mastery of the video converence application used in the material delivery process is very important to master as a substitute for face-to-face learning. The following is student digital literacy data on mastery of the video converence application:

Table 6. Mastery of digital literacy in video conference application

\begin{tabular}{lcc}
\hline \multicolumn{1}{c}{ Platform } & Score & Category \\
\hline Zoom Meeting & 231 & High \\
Jitsi & 104 & Low \\
Google Meet & 212 & High \\
Sisco Webex & 119 & Low \\
\hline \multicolumn{1}{c}{ Average } & 167 & Medium \\
\hline
\end{tabular}

Source: Research Data

The table above shows that the average student mastery of the video converence application falls into the "Medium" category.

Table 7. Percentage of digital literacy mastery in video conference application

\begin{tabular}{lcccc}
\hline \multicolumn{1}{c}{ Aspect } & Zoom meeting & Jitsi & Google Meet & Cisco Webex \\
\hline $\begin{array}{l}\text { Mastering as a host and } \\
\text { performing various existing }\end{array}$ & $42,86 \%$ & $5,36 \%$ & $33,93 \%$ & $14,29 \%$ \\
features & $26,79 \%$ & $7,14 \%$ & $21,43 \%$ & $3,57 \%$ \\
Mastering as a host & $30,36 \%$ & $7,14 \%$ & $35,71 \%$ & $10,71 \%$ \\
Master as a participant & $0,00 \%$ & $28,57 \%$ & $7,14 \%$ & $23,21 \%$ \\
Just knowing & $0,00 \%$ & $51,79 \%$ & $1,79 \%$ & $48,21 \%$ \\
Do not know & $100 \%$ & $100 \%$ & $100 \%$ & $100 \%$ \\
\hline \multicolumn{1}{c}{ Amount } & & & &
\end{tabular}

Source: Research Data

The table above shows that in the Zoom meeting and Google Meet applications the majority of students master as hosts and perform various existing features. In Jitsi and Cisco Webex applications, the majority of students do not know about these applications.

\subsection{Mastery of supporting media for online assignments}

Mastery of supporting media for online assignments is no less important in order to support the achievement of learning outcomes. In the implementation of e-learning, the assignment given by the lecturer is one of the benchmarks for the success rate of learning. The following is digital literacy data on the mastery of media to support online task making: 
Table 8. Mastery of digital literacy media to support online task creation

\begin{tabular}{lcc}
\hline \multicolumn{1}{c}{ Platform } & Score & Category \\
\hline Email & 262 & High \\
Scanner & 225 & High \\
Converter file & 216 & High \\
Compress file & 220 & High \\
Video/picture editor & 178 & Medium \\
\hline \multicolumn{1}{c}{ Amount } & 220 & High
\end{tabular}

The table above shows that the average student mastery of supporting applications for online assignment is in the "High" category.

Table 9. Percentage of mastery of digital media literacy to support online task creation

\begin{tabular}{lccccc}
\hline \multicolumn{1}{c}{ Aspect } & Email & Scanner & $\begin{array}{c}\text { Converter } \\
\text { file }\end{array}$ & $\begin{array}{c}\text { Media } \\
\text { Compress file }\end{array}$ & $\begin{array}{c}\text { Video/picture } \\
\text { editor }\end{array}$ \\
\hline $\begin{array}{l}\text { Master how some of the } \\
\text { features and content both } \\
\text { offline and online work }\end{array}$ & $76,79 \%$ & $46,43 \%$ & $50,00 \%$ & $50,00 \%$ & $23,21 \%$ \\
$\begin{array}{l}\text { Know how it works and have } \\
\text { used it }\end{array}$ & $16,07 \%$ & $23,21 \%$ & $8,93 \%$ & $16,07 \%$ & $14,29 \%$ \\
Know how to work & $5,36 \%$ & $19,64 \%$ & $23,21 \%$ & $16,07 \%$ & $28,57 \%$ \\
Just knowing & $1,79 \%$ & $7,14 \%$ & $12,50 \%$ & $12,50 \%$ & $25,00 \%$ \\
Do not know & $0,00 \%$ & $3,57 \%$ & $5,36 \%$ & $5,36 \%$ & $8,93 \%$ \\
\hline \multicolumn{1}{c}{ Amount } & $100 \%$ & $100 \%$ & $100 \%$ & $100 \%$ & $100 \%$ \\
\hline
\end{tabular}

Source: Research Data

The table above shows that the mostly of students have mastered the workings of several features and content both offline and online on email, scanner, converter files and compressed media files. Meanwhile, in the video / picture editor the mostly of students know how it works.

The graph of the research results on the four indicators examined in this study on the students of the Doctoral Program in Sports Education, State University of Semarang are as follows: 


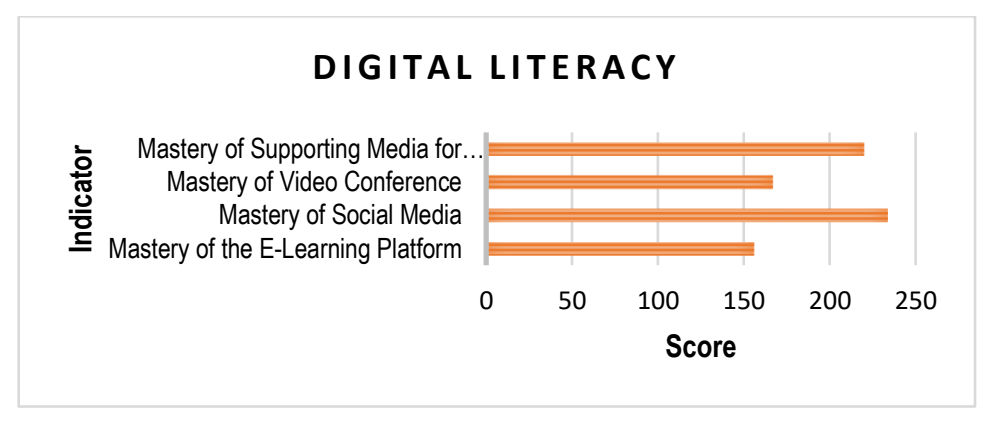

Fig. 1. Student digital literacy

\section{Discussion}

Mastery of social media ranks highest on the average percentage of several digital literacy indicators for students in this study. The use of social media as part of e-learning supports the success of the learning process and achievement. This social media is a communication bridge and indirect interaction between students and lecturers and education staff. Communication could be done personally between student and lecture in groups. Previous research states that digital literacy plays a role in making interaction and communication effective during the learning process [4]. Digital content must be communicated effectively for become a useful educational medium. Using social networking sites like Facebook, Twitter, and Instagram requires users to understand and manipulate information in various formats. Being able to communicate digital content using mobile devices such as cellphones and tablets provides convenience and immediacy in the communication process for lecturers and students [7]. The phenomenon of digital social networking in the last decade, mostly refers to internet-based services such as Facebook, Instagram and Twitter which are platforms that are often used by the public, this is interesting when studying the sub-variable relations related to existing social media. included in the concept of digital literacy extensively and its relationship to online learning academic performance. Beyond the primary purpose of bringing entertainment to the public from these social media platforms, active social media can influence learning in new ways that were never thought of before [8].

Mastery of supporting media for online assignment is the second highest in the average percentage of students' digital literacy. One of the assessments taken by lecturers is from evaluations in the form of assignments to students. The assignments collected by students are not necessarily written but can also be in the form of pictures, tables, graphics or videos. Editing of tasks becomes a necessity when on certain platforms there are restrictions on the type of file sent (JPG, PDF, Word, Excel, MP4, MP3), the size of the file sent and the format of it. From the assignments collected by students, it could be seen the level of aesthetics, creativity and innovation of each student. As stated in previous researchers, quality higher education is one of the prerequisites for the delivery of knowledge and skills development. The quality on education consists of both visible (material) and invisible elements. Developing and developed countries need to guarantee the quality on education to equip students to face a competitive world. Educational institutions do not only focus on education but also involve students in research, creativity, and innovation [9]. Digital literacy skills are one of the most important skills for our students today. Students need to express their ideas in digital media [10]. 
Video converence is very effective for use during the new normal period in class opening and even in conducting training, seminars and conferences to prevent COVID-19 infection and to follow quarantine protocols [11]. Mastery of the video converence application ranks third in the average percentage of students' digital literacy. This video converence application is the focus, especially in the virtual lecture process. Where this virtual lecture process is core of elearning. In this virtual lecture, there is a complex online interaction, communication, discussion and question and answer between students and lecturers.

Mastery of the e-learning platform ranks fourth in the average percentage of students' digital literacy. The statement about the role of the e-learning platform in the learning process in earlier research, namely about the use of Google Classroom, is very useful in improving the abilities and skills of each student. Students can study on their own and through mentoring. While the role of supervisor is very vital for students to absorb the knowledge being taught, students can easily gain competence from their supervisor [12]. E-learning refers to the use of Internet technology to gift multiple solutions that increase knowledge and performance. E-learning could be used by medical educators to increase the efficiency and effectiveness of educational interventions in the face of social, scientific and pedagogical challenges [13]. Higher education should strengthen the main problems for the transformation of conventional learning into elearning, especially communication, teaching and digital competencies.

Students feel that related to that the applications of e-learning is that e-learning requires proper technological skills [14]. E-learning refers to the use of information and communication technology to allow access to online learning / teaching resources [15]. Higher levels of digital literacy positively affect high learning outcomes on student academic performance [8]. Digital literacy is a means to shape students' abilities to think analytically, synthetically, critically, imaginatively and creatively. The applications of digital literacy in lectures is very important to achievement the awareness of all students in seeing literacy skills as a measure of the progress of a nation. Mastery of digital literacy could be a prerequisite in the online learning process for students using digital sources and devices.

\section{Conclusion}

The results showed that of the four indicators examined in this study that the students of the Doctoral Program in Sports Education, State University of Semarang on the indicators of mastery of the e-learning platform included in the "Medium", the indicators of mastery of social media included in the "High", the indicators of mastery the video converence application included in the "Medium", and the indicators of mastery of supporting media for online task creation included in the "High" category.

The average percentage score of fours digital literacy indicators of students from the highest score order is mastery of social media, mastery of supporting media for online assignment, mastery of video converence applications and mastery of the e-learning platform. The higher the level of digital literacy positively affects student learning outcomes and academic performance.

Acknowledgment. We would like to thank the Doctoral Program in Sports Education, Semarang State University, Surabaya State University Sports Science Faculty \& the Universitas Pendidikan Indonesia (UPI). 


\section{References}

[1] W. Wargadinata, I. Maimunah, E. Dewi, and Z. Rofiq. Student's Responses on Learning in the Early COVID-19 Pandemic. Tadris J. Kegur. dan Ilmu Tarb. 2020; 5 (1): 141-153. doi: 10.24042/tadris.v5i1.6153.

[2] E. D. R. Lilis Ardini, Ulfah Setia Iswara. JKBM The Effectiveness of Using E-Learning as Learning Media. 2020; 7: 72-81. doi: 10.31289/jkbm.v7i1.4333.

[3] S. F. A. Widodo, Y. E. Wibowo, and W. Wagiran. Online learning readiness during the Covid-19 pandemic. J. Phys. Conf. Ser. 2020; 1700 (1). doi: 10.1088/1742-6596/1700/1/012033.

[4] A. Irhandayaningsih. Pengukuran literasi digital pada peserta pembelajaran daring di masa pandemi covid-19. Anuva. 2020; 4 (2): 231-240.

[5] S. Tejedor, L. Cervi, A. Pérez-Escoda, and F. T. Jumbo. Digital literacy and higher education during COVID-19 lockdown: Spain, Italy, and Ecuador. Publications. 2020; 8 (4): 1-17. doi: 10.3390/publications8040048.

[6] V. E. Z. N. Liansari. Realitas Penerapan Literasi Digital bagi Mahasiswa FKIP Universitas Muhammadiyah Sidoarjo. The ICECRS 2018; 1 (3): 241-252. doi: 10.21070/picecrs.v1i3.1397.

[7] H. A. Spires, C. Medlock Paul, and S. N. Kerkhoff. Digital Literacy for the 21st Century. 2018. no. July: 12-21. doi: 10.4018/978-1-5225-7659-4.ch002.

[8] G. P. Yustika and S. Iswati. Digital Literacy in Formal Online Education: A Short Review. Din. Pendidik. 2020; 15 (1): 66-76. doi: 10.15294/dp.v15i1.23779.

[9] M. S. N. A. M. A. Elumalai, K. V., Sankar, J. P., R, K., John, J. A., Menon, N., Alqahtani. Factors Affecting the Organizational L Evel a Doption of. J. Inf. Technol. Educ. Res. 2020; 19: 731-753.

[10] B. S. K. Chan, D. Churchill, and T. K. F. Chiu. Digital Literacy Learning In Higher Education Through Digital Storytelling Approach. J. Int. Educ. Res. 2017; 13 (1): 1-16. doi: 10.19030/jier.v13i1.9907.

[11] A. Rahmat. The Impact of Video Conferencing Platform in All. AKSARA J. Ilmu Pendidik. Nonforma. 2021; 7 (1): 15-18.

[12] N. Alim, W. Linda, F. Gunawan, and M. S. M. Saad. The effectiveness of Google classroom as an instructional media: A case of state islamic institute of Kendari, Indonesia. Humanit. Soc. Sci. Rev. 2019; 7 (2): 240-246. doi: 10.18510/hssr.2019.7227.

[13] O. Oludare Jethro, A. Moradeke Grace, and A. Kolawole Thomas. E-Learning and Its Effects on Teaching and Learning in a Global Age. Int. J. Acad. Res. Bus. Soc. Sci. 2012; 2 (1): 2222-6990.

[14] F. Rahmawati. E-Learning Implementation: Its Opportunities and Drawbacks Perceived by EFL Students. J. Foreign Languange Teach. Learn. 2016; 1(1). doi: 10.18196/ftl.111.

[15] H. K. Pei Zhao, Sara Sintonen, K. L. Currie, and J.Courduff. The pedagogical functions of arts and cultural-heritage education with ICTs in museums. Int. J. Instr. Technol. Distance Learn. 2015. p. 7. 